\title{
ADEQUATE REPRESENTATION OF PERSONS BELONGING TO NATIONAL MINORITIES IN PUBLIC SECTOR: THE NATURE, CONTENT AND SCOPE OF OBLIGATIONS IN THE COMMENTS OF THE ADVISORY COMMITTEE FOR THE FRAMEWORK CONVENTION ${ }^{* *}$
}

\begin{abstract}
Adequate representation of persons of minority origin in public sector bodies is one of the conditions for their effective participation in public affairs, as prescribed in Article 15 of the Framework Convention for the Protection of National Minorities. To establish whether a State Party fulfils this requirement, the Advisory Committee for the Framework Convention has developed the standard of adequate representation. The aspect of the standard which concerns the adequate representation of persons of minority origin in non-elected public sector bodies is still vague and insufficiently developed. That is a source of uncertainty as to the obligations of the State Parties and the appropriate methods for their realisation. The paper investigates the nature, content and scope of obligations ensuing from this particular aspect of the standard of adequate representation with the aim to contribute to its further normative articulation. The investigation is carried out by analysing the thematic commentaries and country-specific opinions of the Advisory Committee.

Keywords: Article 15 of the Framework Convention for the Protection of National Minorities, standard of adequate representation, non-elected public sector bodies, legal obligations, Advisory Committee.

\section{Introduction}

Presence of persons of minority background in the workforce of public sector bodies is one of the conditions for their effective participation in public affairs, as laid

\footnotetext{
*PhD, Research Fellow, Institute of Comparative Law, Belgrade, Serbia, e-mail: milicavmatijevic@gmail.com, ORCID ID: 0000-0002-2459-9201

** The paper is based on the comprehensive research of best practices for adequate representation of persons belonging to national minorities in public sector, conducted by the author for the needs of the EU-funded Project "Support of affirmative measures related to employment of national minorities in public sector", which was implemented in the Republic of Serbia between December 2018 and October 2020 by the GFA Consulting Group.
} 
down in Article 15 of the Framework Convention for the Protection of National Minorities (Framework Convention, ETS 157). Whether the level of their presence is sufficient for the achievement of this goal is evaluated against the standard of adequate representation. The standard of adequate representation of persons belonging to national minorities in public sector bodies is a legal standard which specifies requirements that are either necessary or sufficient for meeting the related legal obligations ensuing from Article 15. As such, it should guide activities of the State Parties to the Framework Convention and serve as the point of reference for their evaluation in the monitoring procedure. ${ }^{1}$

For several reasons, which have been tackled elsewhere, the application of the standard of adequate representation is characterised by a lot of vagueness and the resulting uncertainty (Matijević, 2019a, pp. 22-23). That is, in particular, true for its aspect that concerns adequate representation of persons of minority origin in non-elected public bodies, which is the subject of this paper. A closer look at the interpretations of Article 15 given by the Advisory Committee for the Framework Convention ${ }^{2}$ shows that the answer to the question of what does it take to meet the standard of adequate representation when it comes to the non-elected public sector bodies is still sought in a confusing blend of references to the broad human rights ideals, such as social cohesion, inclusive governance, fairness, and examples of best practices.

To contribute to the further normative development of this particular aspect of the standard of adequate representation, in my previous work on the subject I tried to identify its main objectives (Matijević, 2019a). In this paper, I will undertake an initial investigation into the nature, content and scope of obligations arising under the standard of adequate representation of persons of minority origin in non-elected public sector bodies. While the purpose of the earlier analysis was to provide an elaborate answer to the question of why should the State Parties make sure that persons of minority origin are adequately represented in their public sector bodies, the purpose of this one is to provide a clearer view on how to realise this duty. The broader goal of the paper remains to contribute to the further normative articulation of this, so far, underdeveloped subtype of the standard of adequate representation.

The term "non-elected public bodies" is in the paper used as an opposite to "elected public bodies" in order to delineate the specific aspect of the standard of adequate representation that is its subject matter. ${ }^{3}$ Given that the term has been rarely used and even more rarely defined in the literature, at least a brief explanation should be given of what is

\footnotetext{
${ }^{1}$ The Framework Convention for the Protection of National Minorities provides for a system of monitoring of its implementation by the States Parties. The monitoring procedure has two phases. In the first phase, the Advisory Committee carries an evaluation of minority legislation and practice in a State Party and adopts a country-specific opinion. Following the adoption of an opinion by the Advisory Committee, the Committee of Ministers adopts a resolution which contains conclusions on the implementation of minority rights recognised in the Framework Convention in the state under review and recommendations on how to improve it.

${ }^{2}$ Further: "the Advisory Committee".

${ }^{3}$ The distinction between the elected and non-elected public bodies is also present in the Advisory Committee's comments on Article 15. However, instead of using the term "non-elected public bodies", the Advisory Committee in its comments refers to the executive bodies and public services. See, for instance, Opinion on Georgia (2009, p. 51, paras. 203 and 204).
} 
here meant under the notion of "non-elected public bodies". First of all, they should not be confused with what is in the literature referred to as "quangos" or "non-departmental public bodies", that is the bodies which are financed from public resources and fulfil a public function, but with some degree of independence vis-à-vis elected government (Smith \& Flinders, 1999, p. 17). ${ }^{4}$ In fact, the term "non-elected public bodies" in the paper refers to the entities which belong to the concept of "public administration" in the most traditional meaning of it as the entities governed by public law and established for the execution of public law (Wilson, 1887, p. 212). ${ }^{5}$ Differently from the elected public bodies, the non-elected public bodies are here taken to signify those bodies whose main activities are performed by persons who act from the position of employees and not as representatives of interest of societal groups. In other words, our analysis concerns public bodies which fulfil their public function through persons who occupy a position within their organisational structure, not based on their political party affiliations or associations to some segment of the population, but based on their specific skills and expertise. Naturally, their workforce is for the major part composed of civil servants or of the broader category of public servants, but it can also be made of employees who do not have the status of public servants, such is the case with the staff of public companies. Here employed notion of "non-elected public bodies", as such, includes the public administration bodies at all territorial levels, educational, health care and other public institutions, as well as the stateowned companies providing public goods. ${ }^{6}$

The investigation into the nature, content and scope of obligations ensuing from the standard of adequate representation is done primarily through the analysis of the Advisory Committee's interpretations of the duty to establish conditions for effective participation of persons belonging to national minorities in public affairs. The investigation departed from the interpretations of Article 15 and the related provisions of the Framework Convention found in its thematic commentaries. Then it was broadened to include the views expressed by the Advisory Committee in its country-specific opinions delivered in the course of the monitoring procedure.

The paper is structured in the following way. The nature and content of the obligations arising under the standard of adequate representation are analysed in the first part of the paper. In the second part of the paper, I explore the scope of these obligations with regards to the territorial level for which the public sector body was established. The scope of the obligations with regards to the competences of the public bodies is investigated in the third part of the paper. In conclusion, I briefly discuss the importance of further normative development of the standard of adequate representation.

\footnotetext{
${ }^{4}$ See, also, Knox (1998, pp. 159-160, fn. 13).

${ }^{5}$ For an elaborate presentation of the public administration approach to the public sector, see Lane (2000, pp. 2-13).

${ }^{6}$ The "boundary problems within the public sector", as Lienert (2009, p. 27) calls ambiguities in determining the scope of the notion of public sector, are as well and unavoidable limitation of the here defined notion of "non-elected public bodies". Being only an element of the notion of public sector, the notion of "non-elected public bodies" suffers from the same problems in setting the boundaries between market and non-market activities which trouble those who attempt to define "public sector". On the lack of a universal definition of public sector, see Eechoud (2006, p. 280).
} 


\section{Nature of obligations}

Due to the great differences in the position, needs and characteristics of different European minorities, the drafters of the Framework Convention could go only thus far as to lay down the most important principles for their protection (Stekette, 2001, p. 4). That is reflected in the legal character of its provisions, which are not directly applicable but programme-type provisions setting out the objectives to be pursued by the State Parties for an effective legal and institutional protection of national minorities. ${ }^{7}$ Chiefly for this reason, the State Parties have a very broad margin of discretion in the choice of measures for the implementation of the Framework Convention (Explanatory Report to the Framework Convention for the Protection of National Minorities, p. 12, para. 11).

This general feature of the Framework Convention is even more pronounced when it comes to Article 15. The text of Article 15 is phrased in a language vaguer than the rest of the Convention, thus leaving to the State Parties an even broader discretion when it comes to the means for the realisation of duties there established (Verstichel, 2004, p. 194). Different minority groups have not only different needs and interests but also different capacities to participate in the public affairs of the country. For that reason, "a measure that leads to effective participation in one State Party", as the Advisory Committee observes, "does not necessarily have the same impact in another context" (Commentary No. 2, p. 36, para. 148).

However, the wide margin of discretion does not mean that the State Parties can meet their Article 15 obligations by merely trying to achieve the objectives laid down in its text (Estébanez, 2005, p. 278). The obligations of the State Parties arising from Article 15 and the standard of adequate representation are not obligations of conduct but obligations of result (Malloy at al., 2009, p. 96). Differently from the obligations of conduct, the obligations of result are binding as to the results to be achieved, and they are breached when the result required by them do not occur (Economides, 2010, p. 377). ${ }^{8}$ This means that the State Parties' duty is not to give their best to secure conditions for adequate representation of persons of minority origin in their public sector bodies, but to achieve the adequate representation.

Having said that, on the more detailed reading of the comments of the Advisory Committee, one can also notice that the distinction between the obligations of result and the obligations of conduct often tends to be blurred because of the long-term perspective inbuilt in the provisions of the Framework Convention (Commentary No. 2, p. 36, para. 149). ${ }^{9}$ When it comes to the goal of adequate representation implicit in the goal of effective

\footnotetext{
7 Their programme-type character could also be ascribed to the lack of consensus over the very basic normative issues, such as "the issues of right-holders and the legal nature of specific rights" (Jovanović, 2005, p. 628), characterising since the very beginning the normative multiculturalism, the raise of which led to the adoption of the Framework Convention. The price of it was a limited possibility for a solid articulation of the legal obligations of the State Parties to the Framework Convention.

${ }^{8}$ On the distinction between the obligations of conduct and obligations of result under international law, see also Wolfrum (2011).

${ }^{9}$ See, for instance, Commentary No. 2 (p. 69, para. 149).
} 
participation in public affairs, we can observe that Article 15 does not require from the State Parties achievement of some directly measurable targets such as, for instance, that their public sector workforce numerically mirrors the ethnic composition of their population. ${ }^{10}$ Instead, the State Parties are expected to create an environment in which adequate representation of persons of minority origin in public sector will become a lasting result of a consistent recognition of the special needs of minority communities by their legal and institutional systems. These special needs and position of minority communities are clearly reflected in the objectives behind the standard of adequate representation, which could be summarised as elimination of prejudice, equal access to public services and accommodation of identity-related needs of national minorities.

Naturally, what will be the most appropriate measures to achieve these objectives depends on the specific circumstances of the country under consideration. Firstly, it depends on the features and needs of a minority group whose adequate representation is to be secured. As observed by the Advisory Committee in its interpretation of the relationship between the concept of full and effective equality and the linguistic rights guaranteed in the Convention that also sheds light on the standard of adequate representation:

"[...] the principle of equality does not presuppose identical treatment of and approaches to all languages and situations. On the contrary, measures to promote equality must be targeted to meet the specific needs of the speakers of various minority languages. Separate provisions may be necessary for the speakers of languages of numerically smaller minorities to ensure the revitalisation of their language in public life, while other, more widely spoken minority languages, may require other methods of promotion" (Commentary No. 3, p. 10, para. 27).

The objectives behind the standard of adequate representation point to the strong interrelatedness between the concrete legal obligations ensuing from the standard of adequate representation and the features of a minority group. Large minority groups concentrated in some parts of a country usually demand that their linguistic rights are secured on a par with the state language in the public bodies operating in the territories they settle and show interest to participate in public affairs of a country as a whole. On the other hand, the agenda of smaller and dispersed minorities is usually more concerned with their adequate representation in the public bodies which have a particular say on the matters that are affecting them the most. These could be the public bodies in charge of providing services in the access to which they face particular obstacles, or specialised bodies for the preservation of their language and culture, etc. Given the diverse needs of different European minority groups, in its recommendations on how to meet the standard of adequate representation, the Advisory Committee only occasionally delivers recommendations of a

\footnotetext{
${ }^{10}$ On the contrary, according to the Committee, "[m] easures which aim to reach a rigid, mathematical equality in the representation of various groups, [...] should be avoided "[because] [t]hey risk undermining the effective functioning of the State structure and can lead to the creation of separate structures in the society". (Commentary No. 2, p. 59, para. 123).
} 
general character. Instead, its recommendations are for their major part made of references to the best practices of the State Parties identified in the process of monitoring.

When it comes to the differences between the countries related to the financial and other resources needed for the realisation of the standard of adequate representation, they are not among the factors which could limit the scope of obligations established under the standard. At best, given the long-term perspective inbuilt in the provisions of Article 15, lower financial, institutional and other resources could to some extent and for some time soften the negative comments of the Committee. ${ }^{11}$ The underrepresentation of persons of minority origin in the workforce of the public sector bodies is in most cases consequence of structural discrimination, and the remedial action often demands complex institutional changes requiring significant financial and administrative resources. Moreover, implementation of other minority rights which is a prior condition for the realisation of the standard of adequate representation, presents in itself a resource-intensive task. When the Advisory Committee finds that a State Party faces significant economic difficulties, this could to some extent lower its expectations $v i s-\grave{a}$-vis the pace with which the standard of adequate representation is to be realised. However, the lack of financial, administrative and other resources cannot absolve the State Party from its duty to ensure adequate representation of persons belonging to minority communities in the non-elected public sector bodies. Nor it could ever become justification for a lasting underperformance and negative status quo in the realisation of obligations ensuing from the standard of adequate representation.

The Advisory Committee's awareness of various difficulties which could follow the realisation of the standard of adequate representation encompasses as well those arising from the competing economic and other objectives pursued simultaneously by the State Parties such as, for instance, cut-backs in the number of public servants through the fiscal austerity measures. The Committee is also mindful of the fact that employment-related measures aimed at greater representation of national minorities in public bodies could cause tension and resentment in the countries with high unemployment rates and where a significant portion of the population works in the grey sector (Opinion on Macedonia, $\mathrm{p}$. 23, para. 97). ${ }^{12}$ However, as said, this would not affect the content and scope of obligations arising under the standard, but could for a while render the tone of the Committee's negative opinion less harsh.

\section{The scope of obligations with regards to the territorial level of public sector body}

The general rule found in the Advisory Committee's comments on the standard of adequate representation is that all public sector bodies are subject to obligations ensuing from the standard, but to a different degree and in a different way. The public sector of the

\footnotetext{
${ }^{11}$ See, for instance, Opinion on Georgia (p. 8, para. 18).

12 The reports of the civil sector organisations in other countries in the region also point that the use of some of the recruitment-related measures, such as the affirmative action measures, despite their noble aims could have negative ramifications on the relationship between the majority and minority communities. See, for instance, Đorđević et al. (2018, pp. 98-99).
} 
modern European states is organised as a complex network of bodies established at the central, local and regional level. The method of its territorial organisation and the degree of its decentralisation have an important place in the Advisory Committee's doctrine of the standard of adequate representation. Its analysis shows that the answer to the question of the territorial level of the public sector that should be the primary target of measures aimed at adequate representation is to be guided by the three basic rules:

I. The degree of decentralisation dictates which territorial level of public sector should be the primary target of measures aimed at achieving adequate representation.

This first rule shows that when a state is highly decentralised and its regional and municipal public sector bodies have very broad competences, the Advisory Committee will primarily look into the level of representation in these bodies. The Advisory Committee in its comments underlines the importance of the constitutional organisation of a state and notes that "subnational forms of government and minority autonomous self-governments can be valuable tools to foster effective participation of persons belonging to national minorities in many areas of life." (Commentary No. 2, p. 8). But to what extent the emphasis would be on the regional and municipal public bodies in its evaluation also depends on whether these are actually in a position to fully realise such broad competences. ${ }^{13}$ In other words, it would depend on whether they were given the necessary means, including the financial ones, to exercise their powers effectively (Opinion on Montenegro, p. 32, para. 104).

II. The measures aimed at adequate representation should target in particular public bodies situated in areas inhabited by national minorities traditionally or in substantial numbers.

Adequate representation in subnational segments of public sector, including the local level public bodies, is especially important in the parts of the country where persons belonging to national minorities live compactly (Commentary No. 2, p. 32, para. 129). The exclusive use of the state language in these public bodies may seriously hamper the participation of national minorities in public affairs (Commentary No. 3, p. 29, para. 93). Under Article 10, para. 2, the State Parties are expected to "ensure, as far as possible, the conditions which would make it possible to use the minority language in relations between those persons and the administrative authorities". One of the main methods to create conditions for the use of minority languages before public bodies situated in areas inhabited

\footnotetext{
${ }^{13}$ A good illustration of this are findings of an analysis of the official use of minority languages in Serbia, according to which almost all public bodies which were providing administrative services in minority languages faced financial difficulties due to the fact that the expenses incurred in this way were not budgeted for in the process of allocation of financial means for the realisation of mandate of these bodies. The author notes that the existing system of financing did not make any difference between the bodies situated in the municipalities where none of the minority languages were in the official use and those where several minority languages had the status of languages in the official use. See Pavlović (2019, p. 55).
} 
by national minorities is to undertake proactive measures for the recruitment of persons of minority origin or in other ways ensure their adequate representation in these bodies. ${ }^{14}$

III. The central level public bodies are also subject to the obligations arising under the standard of adequate representation.

No matter to what degree public sector of a State Party is decentralised, "the decentralisation process must not relieve the central authorities of their overall responsibility regarding the participation of persons belonging to minorities" (Opinion on Macedonia, $\mathrm{p}$. 24 , para. 101). The obligations arising under the standard of adequate representation which concern the central level public bodies ensue in the first place from the relationship between Article 15 and Article 10, para. 2. The second article, which provides the link between the language-related needs of national minorities and the standard of adequate representation, as noted, requires from the State Parties to ensure conditions for the use of minority languages before administrative authorities in the areas inhabited by national minorities. For the state-level public bodies located in these territories, adequate representation of persons of minority origin in their workforce presents a way to fulfil that duty. ${ }^{15}$

When it comes to the public bodies situated outside areas traditionally inhabited by national minorities, the Advisory Committee says that they "should remain committed to their general responsibility resulting from their international obligations and the national legal framework regarding participation of persons belonging to national minorities in various spheres" (Commentary No. 2, p. 33, para. 132). ${ }^{16}$ Adequate representation of persons belonging to national minorities in the central level public bodies is a precondition for their effective participation in the regulatory processes which concerns matters of special interest for national minorities. Participation in public affairs through the adequate representation of national minorities in the central level public bodies can as well serve as a channel through which "the particular concerns of persons belonging to national minorities are taken into account, but also to make it possible for them to influence the general direction of development in society" (Commentary No. 2, p. 12, para. 17). For that reason, in its country-specific opinions, the Advisory Committee standardly insists on adequate participation of persons belonging to national minorities in the executive bodies.

Apart from these general reasons, adequate representation in the central level public bodies is also essential to ensure that matters of concern of numerically smaller minorities and of the so-called "dispersed" minorities are adequately addressed. In relation to this, the Advisory Committee primarily refers to the needs of persons belonging to Roma community often dispersed in the different regions of the country (Commentary No. 2, p. 8, p. 31, para. 124).

\footnotetext{
${ }^{14}$ See, for instance, Opinion on Bulgaria (p. 28, para. 107).

${ }^{15}$ See on this Vacca $(2016$, p. 2).

${ }^{16}$ For an overview of legal regulation of the official use of minority languages before the public administration bodies in several European countries see Đurić (2019, pp. 56-63).
} 


\section{The scope of obligations with regards to the competences of public sector bodies}

On a number of occasions, the Advisory Committee has reiterated that the duty to ensure adequate representation of persons belonging to national minorities applies to public bodies active in all main segments of public life (Opinion on Macedonia, p. 23, para. 98). As observed by the Committee, "[d]ifficulties in the various sectors are often connected and mutually reinforcing and they can lead to a spiral of exclusion from socio-economic participation" (Commentary No. 2, p. 18, para. 47). For that reason, employment-related or other measures that could increase their level of representation should be used within the diverse public bodies (Opinion on Latvia, p. 39, para. 162).

Apart from this general rule, the Committee also points to the segments of public sector which are essential for the realisation of the objectives behind the standard of adequate representation. ${ }^{17}$ The list of sectors in which it is especially important to ensure adequate representation to a great extent follows the list of public services which are in the Framework Convention identified as vital for the realisation of the rights of national minorities. These are, as it ensues from the provisions contained in Articles 6 to 14 of the Convention, media services ${ }^{18}$, administrative services ${ }^{19}$, education ${ }^{20}$ and health care ${ }^{21}$.

In its observations on the areas of public life in which adequate representation is of greater importance for minorities, the Committee is particularly guided by the needs of the most vulnerable minority groups, or the most vulnerable sections within minority groups. For that reason, the regulation and delivery of health services is an especially prominent topic in its considerations of the public services where adequate representation of national minorities might be crucial for the realisation of their Article 15 participatory rights. As a consequence of different factors, such as the presence of overt discrimination, low socioeconomic status, geographical isolation, language obstacles and cultural distinctiveness, persons belonging to certain national minorities face more obstacles in access to health care (Commentary No. 2, p. 20, para. 61). From this general observation, the Committee concludes that it is essential to ensure that public bodies in charge of providing health care have the capacity to cater to the specific needs of persons of minority origin. Among the different measures that could be used to this aim, safeguarding adequate representation of persons belonging to national minorities in the workforce of the health sector has special importance. These measures should not be directed only at the health care centres, hospitals and other bodies which provide health care, but also at bodies in charge of planning, organisation and guaranteeing quality of the health care provision:

\footnotetext{
${ }^{17}$ In doing this, the Advisory Committee departs from the very text of Article 15, which requires from the State Parties to ensure effective participation of persons of minority origin in those segments of public affairs which are vital for the rights of national minorities (Commentary No. 2, p. 12, para. 16).

${ }^{18}$ See Commentary No. 2 (p. 34, para. 141).

${ }^{19}$ See Commentary No. 2 (p. 40, para. 160).

${ }^{20}$ See Commentary No. 2 (pp. 40-41, para. 161-165).

${ }^{21}$ See Commentary No. 2 (p. 21, para. 62).
} 
"State Parties should ensure the effective involvement of persons belonging to the minorities concerned in the design, implementation, monitoring and evaluation of measures taken to address problems affecting their health care. [...] Medical and administrative staff employed in health services should receive training on the cultural and linguistic background of national minorities, so that they can adequately respond to the specific needs of persons belonging to national minorities. The employment of health mediators or assistants belonging to national minorities can contribute to improved communication and more appropriate approaches" (Commentary No. 2, p. 21, paras. $62-63){ }^{22}$

Importance of adequate representation of national minorities among medical and administrative staff engaged in the provision of health services is especially emphasised when it comes to the regions settled in substantial numbers by persons of minority origin. According to the Committee, to be able to respond to their needs adequately, the staff engaged in the delivery of health care in these regions should be able to provide health services in minority languages and to respond to the needs ensuing from the cultural and linguistic specificities of national minorities (Commentary No. 3, p. 28, para. 88).

Another observation to be made on the scope of obligations vis-à-vis the competences of public bodies is that the Advisory Committee also pays attention to the representativeness of the staff of bodies entrusted with the matters of special importance for minority groups. The Advisory Committee in principle welcomes the establishment of such specialised bodies at the national, regional or local level, but it also stresses the importance of the recruitment and retention of staff with the minority language skills for a successful realisation of their responsibilities (Commentary No. 2, p. 28, para 104). ${ }^{23}$

\section{Conclusion}

The objective of this paper was to contribute to the further normative articulation of the aspect of the standard of adequate representation which concerns non-elected public sector bodies. Without a clearer view on what does it take to have an adequate representation of persons belonging to national minorities in non-elected public sector bodies, this segment of the Article 15 obligations will be bound to remain a source of misunderstanding both with regards to the duties of the state authorities and the claims that minority groups could reasonably raise. The lack of certainty that characterises the standard often leads to quick-fix solutions. These are especially employed when the negative findings of the Advisory Committee threaten the achievement of another valuable goal. The role of the Advisory Committee's findings in the evaluation of the progress of

\footnotetext{
${ }^{22}$ Footnote omitted.

${ }^{23}$ However, the Advisory Committee cautions that minority-related issues "should not remain exclusively in the domain of specialised governmental bodies", and that "the minority perspective needs to be mainstreamed in general policies at all levels and procedural steps by the actors involved in policy-making" (Commentary no. 2, p. 23, para. 73). Similarly, at p. 28, para. 105.
} 
candidates and potential candidates for the EU membership has increased the importance of the process of monitoring of the implementation of the Framework Convention. That, however, led to the situations where the State Parties adopted laws and policies which in the long run haven not had positive effects on the level of representation of minority groups, but have fulfilled the goal of earning for the State Party a favourable opinion of the Advisory Committee in the period that was decisive for the success of the EU accession process. On some occasions, these solutions were in effect almost as bad as the problem they were trying to resolve. Some of them were potentially damaging for the relationship between the majority and minorities because of the tensions they could have caused in the societies where a great number of jobs belong to the grey economy. Some involved the danger of the creation of parallel structures in society. Others have resulted in only cosmetic changes which have silenced the discussion about the level of representation of minorities in public sector. Eventually, they all led to the futile use of resources that are always scarce when it comes to such elusive aim as the one of full and effective equality between persons belonging to a national minority and those belonging to the majority. ${ }^{24}$ All these problems are additional reasons for the further normative elaboration of the here examined aspect of the standard of adequate representation, both in theory and in practice.

\section{References}

Đorđević, Lj. et al. 2018. Učešće nacionalnih manjina u društvenom i političkom životu Srbije. Belgrade: Ethnicity Research Centre.

Đurić, V. 2019. Službena upotreba jezika nacionalnih manjina u radu organa uprave. Strani pravni život, 3, pp. 49-68.

Economides, C. 2010. Content of the Obligation: Obligations of Means and Obligations of Result. In: Crawford, J., Pellet, A. \& Olleson, S. (eds.), The Law of International Responsibility. Oxford: Oxford University Press, pp. 371-382.

Eechoud, van M. 2006. The Commercialisation of Public Sector Information: Delineating the Issues. In: Guibault, L. \& Hugenholtz, P. B. (eds.), The Future of the Public Domain: Identifying the Commons in Information Law. The Hague: Kluwer Law International, pp. 279-301.

Estébanez, A. M. M. 2005. Council of Europe Policies Concerning the Protection of Linguistic Minorities and the Justiciability of Minority Rights. In: Ghanea, N. \& Xanthaki, A. (eds.), Minorities, Peoples and Self-Determination. Leiden: Martinus Nijhoff Publishers, pp. 269- 298.

Jovanović, M. 2005. Recognizing Minority Identities Through Collective Rights. Human Rights Quarterly, 27(2), pp. 625-651.

\footnotetext{
${ }^{24}$ The illustrations of some or all of the mentioned problems, which in the first place reflect the lack of understanding of what are the objectives, obligations and methods for the realisation of the standard of adequate representation, as well as the urge to fulfil the standard as soon as possible because of the EU accession process, can be found in the Advisory Committee's findings on Serbia, Croatia, North Macedonia and Montenegro. For an analysis of the Serbian experience with the problem of inadequate representation and its attempts to resolve it, see Matijević (2019b).
} 
Knox, C. 1998. The European Model of Service Delivery: A Partnership Approach in Northern Ireland. Public Administration and Development, 18, pp. 151-168.

Lane, J. R. 2000. The Public Sector: Concepts, Models and Approaches. $3^{\text {rd }}$ edition. London: SAGE.

Lienert, I. 2009. Where Does the Public Sector End and the Private Sector Begin? IMF Working Paper, WP/09/122. Available at: https://www.imf.org/en/Publications/ $\mathrm{WP} /$ Issues/2016/12/31/Where-Does-the-Public-Sector-End-and-the-PrivateSector-Begin-23003, (4.12.2020).

Malloy, H. T. et al. 2009. Indicators for Assessing the Impact of the FCNM in its State Parties (Draft Study). Conference: Enhancing the Impact of the Framework Convention. 9 10 October 2008. Strasbourg: European Academy Bolzano, Institute for Minority Rights. Available at: https://rm.coe.int/CoERMPublicCommonSearchServices/ DisplayDCTMContent?documentId=09000016806bd62d, (12.11.2020).

Matijević, V. M. 2019a. Towards a Better Understanding of the Standard of Adequate Representation of Persons Belonging to National Minorities in Public Sector. Strani pravni život, 4, pp. 19-39.

Matijević, V. M. 2019b. Afirmativne mere za zapošljavanje pripadnika nacionalnih manjina u državnoj upravi Republike Srbije: Osvrt na postojeća rešenja. Pravni život, III(11), pp. 589-605.

Pavlović, Z. 2019. Službena upotreba jezika i pisma nacionalnih manjina. In: Varadi, T. (ed.), Prava nacionalnih manjina u ustavnopravnom sistemu Republike Srbije. Collection of papers from the Round Table held on $27^{\text {th }}$ November 2017. Belgrade: Srpska akademija nauka i umetnosti, pp. 43-61.

Smith, J. M. \& Flinders, V. M. 1999. Quangos, Accountability and Reform: The Politics of Quasi-Government. New York: St. Martin's Press in association with Political Economy Research Centre, University of Sheffield.

Stekette, F. 2001. The Framework Convention: A Piece of Art or a Tool for Action?. International Journal of Minority and Group Rights, 8, pp. 1-15.

Vacca, A. 2016. Rights to Use Minority Languages in the Public Administration and Public Institutions: Italy, Spain and the UK. Torino: Giappichelli.

Verstichel, A. 2004. Elaborating a Catalogue of Best Practices of Effective Participation of National Minorities: Review of the Opinions of the Advisory Committee Regarding Article 15 of the Council of Europe Framework Convention for the Protection of National Minorities. European Yearbook of Minority Issues, 2, pp. 165-195.

Wilson, W. 1887. The Study of Administration. Political Science Quarterly, 2(2), pp. 197-222. Wolfrum, R. 2011. Obligation of Result Versus Obligation of Conduct: Some Thoughts About the Implementation of International Obligations. In: Arsanjani, M. H., Cogan, J., Sloane, R., \& Wiessner, S. (eds.). Looking to the Future: Essays on International Law in Honor of W. Michael Reisman. Leiden: Martinus Nijhoff Publishers, pp. 363-383. 


\section{Legal sources}

Advisory Committee on the Framework Convention for the Protection of National Minorities, Commentary No. 1: Commentary on Education under the Framework Convention for the Protection of National Minorities, ACFC/25DOC(2006)002 (adopted on 2 March 2006).

Advisory Committee on the Framework Convention for the Protection of National Minorities, Commentary No. 2: The Effective Participation of Persons Belonging to National Minorities in Cultural, Social and Economic Life and in Public Affairs, ACFC/31DOC(2008)001 (adopted on 27 February 2008).

Advisory Committee on the Framework Convention for the Protection of National Minorities, Commentary No. 3: The Language Rights of Persons Belonging to National Minorities Under the Framework Convention, ACFC/44DOC(2012)001 rev (adopted on 24 May 2012).

Advisory Committee on the Framework Convention for the Protection of National Minorities, Opinion on Bulgaria, ACFC/OP/I(2006)001 (adopted on 27 May 2004). Advisory Committee on the Framework Convention for the Protection of National Minorities, Opinion on "the former Yugoslav Republic of Macedonia", ACFC/ INF/OP/I(2005)001 (adopted on 27 May 2004).

Advisory Committee on the Framework Convention for the Protection of National Minorities, Opinion on Georgia, ACFC/OP/I(2009)001 (adopted on 19 March 2009). Advisory Committee on the Framework Convention for the Protection of National Minorities, Opinion on Latvia, ACFC/OP/I(2008)002 (adopted on 9 October 2008).

Explanatory Report to the Framework Convention for the Protection of National Minorities, European Treaty Series No. 157, Strasbourg (1 February 1995).

Framework Convention for the Protection of National Minorities, European Treaty Series No. 157 (1 February 1995).

\section{Dr Milica V. Matijević}

Naučni saradnik, Institut za uporedno pravo, Beograd, Srbija e-mail:milicavmatijevic@gmail.com

\section{ADEKVATNA ZASTUPLJENOST PRIPADNIKA NACIONALNIH MANJINA U JAVNOM SEKTORU: PRIRODA, SADRŽINA I OBIM OBAVEZA U KOMENTARIMA SAVETODAVNOG KOMITETA ZA OKVIRNU KONVENCIJU}

Sažetak

Adekvatna zastupljenost osoba manjinskog porekla u telima javnog sektora je jedan od uslova za njihovo efikasno učešće u vođenju javnih poslova propisano čl. 15. Okvirne 
konvencije za zaštitu nacionalnih manjina. Stepen ispunjenosti ovog uslova utvrđuje se primenom standarda adekvatne zastupljenosti. Jedan od posebnih aspekata standarda tiče se zastupljenosti pripadnika nacionalnih manjina u tzv. neizabranim telima javnog sektora, odnosno telima koja poslove iz svoje nadležnosti ne sprovode preko izabranih lica, već preko lica koja imaju status državnih ili javnih službenika, nameštenika i drugih zaposlenih. On je do sada ostao nedovoljno razvijen i prilično neodređenog normativnog sadržaja što, kako kod država članica Okvirne Konvencije, tako i kod samih pripadnika nacionalnih manjina, dovodi do ozbiljnih nedoumica u pogledu sadržaja obaveza koje iz njega proističu kao i najpodesnijih metoda za njihovo realizovanje. Autorka se u članku bavi ispitivanjem pravne prirode, sadržaja i obima obaveza koje proizilaze iz ovog posebnog segmenta standarda adekvatne zastupljenosti s ciljem da doprinese njegovom daljem normativnom artikulisanju. Zaključci se zasnivaju na analizi tumačenja čl. 15. i drugih relevantnih odredbi Okvirne Konvencije koja su sadržana u tematskim komentarima i pojedinačnim mišljenjima Savetodavnog komiteta za Okvirnu konvenciju.

Ključne reči: čl. 15. Okvirne konvencije za zaštitu nacionalnih manjina, standard adekvatne zastupljenosti, neizabrana tela javnog sektora, pravne obaveze, Savetodavni komitet za Okvirnu konvenciju.

Article history:

Received: 9 December 2020

Revised: 5 January 2021

Accepted: 20 January 2021 